January 1993

\title{
So Much Success, So Little Joy
}

Robert Neil Gerstman, D.O.

Thomas Jefferson University

Follow this and additional works at: https://jdc.jefferson.edu/jeffjpsychiatry

Part of the Psychiatry Commons

Let us know how access to this document benefits you

\section{Recommended Citation}

Gerstman, D.O., Robert Neil (1993) "So Much Success, So Little Joy," Jefferson Journal of Psychiatry. Vol. 11 : Iss. 1 , Article 15.

DOI: https://doi.org/10.29046/JJP.011.1.007

Available at: https://jdc.jefferson.edu/jeffjpsychiatry/vol11/iss1/15

This Article is brought to you for free and open access by the Jefferson Digital Commons. The Jefferson Digital Commons is a service of Thomas Jefferson University's Center for Teaching and Learning (CTL). The Commons is a showcase for Jefferson books and journals, peer-reviewed scholarly publications, unique historical collections from the University archives, and teaching tools. The Jefferson Digital Commons allows researchers and interested readers anywhere in the world to learn about and keep up to date with Jefferson scholarship. This article has been accepted for inclusion in Jefferson Journal of Psychiatry by an authorized administrator of the Jefferson Digital Commons. For more information, please contact: JeffersonDigitalCommons@jefferson.edu. 


\title{
So Much Success, So Little Joy
}

\author{
GOOD GRIEF: THE STORY OF CHARLES M. SCHULTZ \\ Rheta Grimsley Johnson \\ Pharos Books, New York \\ 1989, \$17.95, 256 pgs.
}

\section{Robert Neil Gerstman, D.O.}

This biography was published in 1989 as a tribute to Charles Schultz's fortieth anniversary of publishing Peanuts. The longevity of his cartoon and the fact that he has drawn each strip by himself is unique. His characters are known in every continent and their trials and tribulations are translated into over twenty languages every day. So why would I recommend this book to the general public, and to psychiatrists and mental health professionals in particular? Because in this authorized biography, Rheta Grimsley Johnson, a nationally renowned syndicated columnist, shows how a man does not have to be crippled by his mental illness and how this man in particular could not have become what he is today without coming to terms with agorophobia and depression.

The early chapters describe how Schultz grew up in Minneapolis as an only child who was close to his mother and father. Significant milestones from his life are mentioned, in particular those which seem to be reflected in Peanuts. For example, the whole family moved to Needles, California during the Great Depression while his father looked for work, eventually moving back to Minneapolis where he graduated from high school. In school he was a C student with very few friends, spending most of his lunch hours by himself and feeling intimidated by the others. A whole chapter is devoted to the woman on whom The Little Red Haired Girl is based. We see that his popular character Charlie Brown reflects some of Schultz's own experiences and feelings.

The critical point in his life, according to Johnson, was his draft into World War II the same week that his mother died from cancer. He never had the opportunity to say good-bye to his mother and according to Johnson, this was an issue he never successfully resolved. He returned from the war and sought work as an art illustrator and as a free lance cartoonist for newspapers while waiting for his big chance to be published in a major newspaper.

The middle chapters furnish more detail on how Schultz was able to get Peanuts published and eventually known in every corner of the globe. The remaining chapters show what day to day operations are currently like with Schultz working in his studio in Santa Clara, California.

Johnson makes clear references throughout this book to the fact that Schultz 
does not enjoy his successes and that he seems to dwell on his disappointments and moments of failure. Each chapter reveals key aspects of his life which demonstrate that this man constantly deals with sadness and, according to Johnson, suffers from agorophobia. He traveled shorter distances as each year went by and ultimately even the trip between his studio in Santa Clara and the offices of United Features Syndicates in Los Angeles became a struggle. The chapters that deal with the financial rewards of his comic strip point out how Schultz is ambivalent to the many millions of dollars he makes each year.

What I found impressive about this book is that it conveys how mental illness influenced the life of one of the most eminent illustrators of this day and how it did so without touting itself as a "psychiatric text" or a "primer." Everyone should read it to learn from Schultz's experience that mental illness is not an obstacle to success. 